\title{
The Case of George Brown: Material Culture and the Missionary Enterprise
}

\author{
Holly Bray
}

This article analyzes the complex and controversial role of material culture in the missionary endeavour of the South Pacific, using as a case study George Brown. Brownô contributions to the European academic community as well as to his Methodist mission offer scholars an exceptional example of how extensive object collection blurs the line between missionary and ethnographer. With reference to detailed sources written by Brown himself, it is argued that his role as a missionary did not limit Brownôs credibility in an academic environment hungry for first-hand accounts of indigenous culture. Furthermore, this role should enhance (not taint) studies of Brownôs legacy; a collection of objects and texts such as his denies a clear categorization as a missionary or as an ethnographer. The context of George Brownôs collecting therefore merits a ñecontextualizationò of sorts, as the stigma surrounding the missionary enterprise often obscures the historical value of such prized research.

In 1853, George Brown, the eighteen-year-old son of an esteemed lawyer from Durham, migrated to New Zealand by virtue that ñit was the farthest place from England. ${ }^{1}$ In spite of Brownô time abroad as a sailor on board a troop-ship and of several appealing job offers from his fatherôs connections, Brown sought a far more intriguing destiny in the islands of the South Pacific. The missionary profession would only appeal to Brown after he had lived with relatives, Reverend and Mrs. Buddle, in Onehunga for some time; yet, as his story shows, something of the adventurer was clearly retained and would prove to be the defining feature of Brownôs career. In fact, George Brown arrived rather late to the missionary field, in a region that had been the subject of economic and theological interest for already many decades. Though Brown would pioneer Methodist missions in the Bismarck Archipelago and elsewhere, he was by no means the first European to encounter Pacific Islanders who were (for the majority) by this time familiar with some form of European trade experience. The details of these encounters, as well as the economic systems of each Island group, vary greatly and defy any generalization of cultural experience. What can be confirmed, however, was the prominent role of material culture in these early transactions, although European appropriation of indigenous objects would later become a highly systematic enterprise. It would then be incorrect to dissociate the missionary endeavour in the South Pacific with the concept of material culture, since European contact with Islanders had been characterized by object transactions and by the economic complexity inherent to this practice. George Brownôs mission field was thus not simply a blank canvas awaiting the imprint of the West, but a group of complex social groups with different ways of interacting with Europeans regarding trade and political relations. Missionary entanglement in material culture becomes a highly relevant area of study if one is to acknowledge the significance of missionariesôinteractions with and interpretations of their host societies, as both interaction and interpretation were often realized through objects on both sides.

\footnotetext{
${ }^{1}$ George Brown, George Brown: D.D., pioneer-missionary and explorer : an autobiography : a narrative of fortyeight years' residence and travel in Samoa, New Britain, New Ireland, New Guinea, and the Solomon Islands (London: Hodder and Stoughton, 1908), 15.
} 
How then must scholars view South Pacific missionaries, if a biased depiction of European colonial and cultural domination over indigenous peoples is thrown aside? It is necessary to reexamine the missionary enterprise without overlooking how missionaries understood their own role within the network of material transactions. To do this, we will analyze the case of Methodist missionary George Brown and the importance of material culture to his mission in the South Pacific. We will see how the European academic community and the South Pacific mission field, being also centered on material culture, created an ambiguous (and later controversial) situation for George Brown as he sought to contribute to both spheres.

Firstly, we must recognize that the response of the academic community to the artifacts brought back from the voyages of Captain Cook was largely one of adaptation. Scholars charged with interpreting these objects and their cultural contexts were desperately in need of a way to conceptualize what they were seeing and reading. Though new revelations have never (and will never) cease to stir up scholarly debate, Cookôs artifacts brought about ña more theoretical discourse which sought to define objects as scientific specimens and set up a way of discussing them that was authorized by rational criteria of some kind..$^{2}$ Thus, as Nicholas Thomas points out, academic discourse adapted over time to be able to rationalize not only the artifacts themselves but also the cultures that produced them. ${ }^{3}$ European scholars were quick to use Cookôs objects as evidence to compare and contrast different Pacific Island cultures in order to form, or to suit, theories about the origin of these societies. Cook $\hat{Q}$ curiosities were then effectively contextualized (or recontextualized) ñas tokens of a nominalized collective existenceò to fabricate cultural identity. ${ }^{4}$ In other words, the Other had taken a new form, that of the Pacific Islander, which was constructed not simply through narratives but through material culture. European academics, using items such as spears and shells, attempted to conceptualize the South Pacific by fabricating an Other that could correspond to the physical realities presented to them. Theories, of course, tend to blossom best in an environment of loose speculation, and such was the case with these curiosities. The objects and the Other that had created them required a place in the human story: all this at a time when ethnography was in its infancy. The urge to classify the many Pacific cultures along the scale of human progress could only be satisfied by ascertaining which technologies or advancements had been adopted on which islands; objects as ñvidence of contact, diffusion, progress or stagnationò spoke to the ñigid materialismò of ethnography for nineteenth-century European philosophers and theorists. ${ }^{5}$ Correspondents in the South Pacific, who were able to send collected objects and accompanying notes, were therefore invaluable to the academic community at this time, and this is precisely where the missionary can often be absorbed into the ethnographic discipline. As Europeans who were in a position to observe indigenous cultures on a day-to-day basis and to amass substantial collections of items from various regions, missionaries found their roles as proselytizers subsumed into academia quite easily by virtue of their supposed credibility as first-hand witnesses of Islander customs. ${ }^{6}$

\footnotetext{
${ }^{2}$ Nicholas Thomas, Entangled Objects: Exchange, Material Culture, and Colonialism in the Pacific (Cambridge, MA: Harvard University Press, 1991), 139-140.

${ }^{3}$ Ibid.

${ }^{4}$ Nicholas Thomas, ñMaterial Culture and Colonial Power: Ethnological Collecting and the Establishment of Colonial Rule in Fiji,ò Man 24, no. 1 (1989): 42-43.

${ }^{5}$ Helen Gardner, ñGifts, Curios and Soulsò from Gathering for God: George Brown in Oceania, (Dunedin: Otago University Press, 2006): 130.

${ }^{6}$ Darrell L. Whiteman, ñMissionary Documents and Anthropological Research,ò Missionaries, Anthropologists and Cultural Change 25, no.1 (1984): 302-303.
} 
We can therefore attribute to the academic community some agency in the blurring of the line between missionary and scientist, as missionary collections and reports were sought after so zealously as trustworthy scholarly sources.

Secondly, to deny that missionaries in the South Pacific were involved in their own networks of material exchange would be to deny the utility of material culture for the cause of Christianity. Barbara Lawson, in her study of the mission endeavour in Erromanga, concludes that ñthe transformation of cultural symbols was an essential component in missionary collecting and more significantly served as a vital aspect of missionizationò: the mission would then seem to require Western recontextualization of objects from indigenous cultures. ${ }^{7}$ In this light, the task of the missionary was indeed a formidable one, for he was required to not only plant the seeds of Christianity but also to remove or change certain aspects of Islander culture for the missionization process to be complete. It was then not enough to add something to the society in question; a certain de-culturalization had to take place (in theory) for Christianity to replace ñheathenismò and not simply adapt to it. The real success of these de-culturalizing efforts is debatable, and remains a question worthy of a separate analysis. What concerns us here is the need for missionaries to represent their success via cultural symbols, or objects representative of hypothetically transformed indigenous culture. This reflects the deep relationship between material culture and the mission effort, because objects were at once the targets of the mission and the way in which the mission measured its symbolic value. ${ }^{8}$ Nicholas Thomas uses the concept of idolatry as an example to illustrate the complexity of this approach, since idols ñcould be abstracted from their context in native worship and destroyed or displayed, [é ] reflect[ing] a broader repudiation of the underlying beliefs. $0^{9}$ Thomas reminds us that conversion is an abstract concept and could not be trumpeted to home congregations in terms as concrete as those of renounced idols. What the repudiation of idols symbolized for missionaries and for Islander converts may have been different theoretically, but it is clear that missionaries often saw their seizure of such items as emblematic of their missionôs achievements and not as the result of conscious indigenous depreciation of the objects. ${ }^{10}$ Conversely, material culture also conveniently worked to highlight the potential of Pacific Islanders and not merely their primitiveness. The beauty of a Melanesian basket weave and the ingenuity of Samoan roofthatching techniques are only some examples of missionariesô appreciative comments with reference to the industry or the aesthetic taste of indigenous peoples. Remarks such as these recur frequently in missionary narratives and in correspondence, possibly due in part to a genuine appreciation of Island material culture but more importantly because positive depictions of the native are instrumental to the missionary endeavour. To say that the Pacific Islander ñwas not totally repugnant, not totally devoid of the seeds of improvement, and indeed already had commendable featuresò was to underline the reason for the mission in the first place: the salvation of souls. ${ }^{11}$ The character of an indigene could not be too desperate, he could not prove

\footnotetext{
${ }^{7}$ Barbara Lawson, ñMissionization, Material Culture Collecting, and Nineteenth-Century Representations in the New Hebrides (Vanuatu),ò Museum Anthropology 18, no. 1 (1994): 34.

${ }^{8}$ For further reading on the missionary enterprise and the consciousness of conversion, Jean and John L. Comaroff present an in-depth analysis in their work Of Revelation and Revolution (Chicago: University of Chicago Press, 1991-1997).

${ }^{9}$ Thomas, Entangled Objects, 153.

${ }^{10}$ This theme appears in George Brownôs writings and in many other missionary texts. One such reference is James Huttonô Missionary Life in the Southern Seas (London: Henry S. King \& Co., 1874), 103.

${ }^{11}$ Thomas, Entangled Objects, 157.
} 
too unyielding to missionary influence, and his morality could not be too debased as to render his fate hopeless. If the purpose of missionaries was to save those ñoverlaid with monstrous forms of superstition or ignorance, ò it was necessary to depict indigenes as worth saving and therefore as human beings with a ñconscience [that could] still respond to the voice of the Gospel of Truth..$^{12}$ This notion was entwined with material culture since indigenous craftsmanship was a way that missionaries and theorists alike categorized Islander peoples and their state of technological ñadvancement.ò Therefore, material culture played a double role with regard to missions: the Othering of a primitive savage could objectify true conversion and help earn funds for the mission, while the Brothering of the indigene proved that the mission was a worthwhile pursuit in the name of a shared humanity.

It was in this environment that George Brown found himself as he was working in the mission field of Samoa and the Bismarck Archipelago in the 1860s and 1870s. Indigenous objects were in great demand on the consumer market, and Brown often gave curios as gifts to his friends and colleagues. As aforesaid, knowledge of indigenous material culture was useful concerning the needs of the mission to secure funds and legitimize his efforts. But what of scientific contributions? The compatibility of material culture in the mission field and the academic communityố desire for on-site ethnographical observations created ideal conditions for an explorer like George Brown to be active in his mission work and be regarded as an authority on the indigenous groups with whom he lived. I will argue that Brownôs rich legacy of collected artifacts, photographic plates and writings defy notions of a clear-cut label or identity that can be applied to Brown and his contributions to ethnography; however, if one is to examine the collection more closely, it becomes evident that George Brown surpassed his role of missionary work on a scale that still raises controversy about his legacy.

On the subject of what George Brown collected, I would firstly comment on what Paula G. Rubel and Abraham Rosman refer to as ñthe more encyclopedic natural history approachò of the Brown collection. ${ }^{13}$ It is true that indigenous weapons and idols figure prominently among Brownô earlier collecting habits; this should perhaps come as no surprise, since the public demand for these specific items was higher than for any others, and Brown was still in a position where funding remained a concern. It may simply have been that Brown had an unstated, greater personal interest in these objects, or perhaps his transactions with indigenous groups yielded these items more than others. What Rubel and Rosman point out, however, is a change in the nature of Brownôs collecting activity throughout his career. The objects that are deemed to be symbolic of heathenism or of indigenous primitivism (like weapons and idols) gradually give way to objects of a more mundane, less sensational nature (like an assortment of New Guinean ear ornaments). Though Brown no doubt took great care in what he chose for his collection, perusal of his catalogue would perhaps lead the reader to believe that Brown was intent on collecting everything. The wide range of objects, especially of those that are quite similar, hint at a collecting attitude less aimed at oddities and more aimed toward scientific data. ${ }^{14}$ To say that

\footnotetext{
${ }^{12}$ Walter G. Ivens, Hints to Missionaries to Melanesia (London: Melanesian Mission Church House, Westminster, 1907), 26.

13 Abraham Rosman and Paula G. Rubel, ñGeorge Brown, Pioneer Missionary and Collector,ò Museum Anthropology 20, no. 1 (1996): 67.

14 The catalogue of the George Brown Collection compiled by the National Museum of Ethnology illustrates this point well with detailed records of over three thousand artefacts.
} 
Brownô collection was a perfectly accurate representation of indigenous material culture would be to overlook complex and long-standing exchange systems between Brown and Islander groups (for example, Brown does not include objects of European manufacture). Nevertheless, Brownô inclusion of ñeverydayò Islander objects is relevant if we are to discuss the purpose of his collecting behaviour. ${ }^{15}$

Where Brown collected is also important to this topic, though the reasons for his pioneer work in the Bismarck Archipelago remain somewhat questionable. Brownôs mobility throughout the South Pacific gained him exposure not only as a missionary, but also as a knowledgeable scholar who was eager to broaden his experience of indigenous ways of life. His readiness to travel, despite illness and prolonged separation from his family, characterized Brownôs career and worked to his advantage both with contact with other Islander cultures and with access to their ethnological treasures. Brownô insistence on missionizing New Britain and New Ireland, seen as ñuntouchedò by extensive interaction with Europeans, has been attributed to his zeal for the missionô expansion and to his scientific curiosity. If the seeds of Christianity were to be planted in New Britain, one could easily anticipate Brownô detailed writings on the New Britain people that would follow and his attempts to appropriate native artifacts through exchange. His desire to go somewhere ñot at all affected by outside influences, ò though it is not unique, still reveals his taste for adventure and the unknown, even if voyages to the Bismarck Archipelago were arranged on the pretext of expanding the Methodist mission. ${ }^{16}$

Finally, reference to Brownô published texts must be made here, to underline the ethnographical nature of these writings. Brown sent most of his collected artifacts overseas for examination and preservation, but his published work constitutes an essential breakdown of the theoristfieldworker relationship, wherein the fieldworker provides data and the theorist is responsible for rationalizing and generalizing what he has been given, usually from a location quite remote from the field. Brownô published writings could be seen as an expression of academic authority based on his unique position in the field of study; one has only to browse r̃Papuans and Polynesians,ò for example, to appreciate the extreme detail of these accounts and the reason why they were valued as creditable scientific research at that time. Brown himself lays claim to his experience ñamongst a purely Papuan people who were absolutely untouched by foreign influences, ò which in turn justifies his rebuttal and scrutiny of contemporary ethnographical concepts of Pacific Island groups. ${ }^{17} \mathrm{He}$ may not have been an expert in botany or ornithology, but with regards to the linguistic and cultural aspects of South Pacific indigenous life, Brownôs style of writing conveys assurance and a deeper analysis much to his credit. His choice to take up the pen and lend his voice to ethnographical theory sets him apart from his fellow missionaries in the South Pacific and raises his status to that of a bona fide ethnographer.

\footnotetext{
${ }^{15}$ Mention of Brownôs extensive appropriation of flora and fauna specimens for natural historians is not here, as it is necessarily excluded from the discipline of ethnography. However, as these specimens were obtained merely for scientific purposes, independent of the mission endeavour, I feel that it is appropriate to at least note them in this section. It is another excellent instance of how George Brown was integrated into the academic sphere through his collecting activities. For an example of one of Brownôs botanical/biological descriptions, please see his Autobiography, pp. 99-100.

${ }^{16}$ George Brown, Melanesians and Polynesians: Their Life Histories Described and Compared (London: Macmillan, 1910), 190.

${ }^{17}$ George Brown, ñPapuans and Polynesians,ò The Journal of the Anthropological Institute of Great Britain and Ireland 16 (1887): 312.
} 
Notwithstanding the argument stated above, that George Brownôs legacy of collections, writings and academic contributions have earned him a place among ethnographers, I do recognize the efforts of contemporary scholars to stress the context in which these items were collected, namely that of the missionary endeavour. Richard Evesôpoint that ñthe collection cannot be divorcedò from the mission field is important to consider; it is precisely the context and subsequent recontextualization of the George Brown collection that fuels modern-day debate over its significance. However, by tracing the role of material culture back to the mission field as well as to academia, I have attempted to avoid ñsanitiz[ing] Brownôs role as a colonial evangelistò or ñunderestimat[ing] the important part played by material culture in missionary discourse and practice..$^{18}$ My argument has acknowledged how missionary discourse uses material culture to meet specific interests or agendas, and that Brown was involved in this agenda through his association with the Methodist mission. I take issue, however, with Evesô idea that missionary practice and ethnological study are fundamentally incompatible. As all scholarly work is biased in some manner, so too is Brownô involvement in ethnography. But to recognize the bias and still value the extraordinary contributions that were made by Brown is essential, not only in this case but in other instances where missionary association with the academic world has been largely discounted as too ñtaintedò to be taken seriously. Though modern scholarship understandably scoffs at many ethnographic theories like diffusionism, the fact remains that George Brownôs collection and writings were viewed by his contemporaries as genuine scholarly research at the time. As an ethnographer and a missionary, George Brown would not escape the colonialist agenda that Richard Eves is so eager to impose upon Brownôs intentions; his writings and artifacts would simply take on a different layer of meaning, where the value of their legacy could still be acknowledged through this second lens, or a new recontextualization.

Recontextualization of ethnographic collections occurs as soon as the objects are appropriated for a different use than that to which they were destined. Barbara Lawson, here citing James Clifford, tells us that ñethnographers ñtextualizeò unwritten behaviour, speech, beliefs, oral tradition, and ritual by gathering data into a corpus, thereby isolating it from the immediate discursive or performative situation. $\mathrm{O}^{19}$ This isolation therefore speaks to the relevance of a ñsecond lensò on every ethnographic collection, since academics are required to interpret what was collected but also the cultural/political/economic context of the collection process. With regard to the George Brown collection, we cannot overlook the value of scientific research, nor can we dissociate Brown with his place in the network between material culture and the missionary enterprise. I have stated that Brown should be contextualized with reference to his mission in the South Pacific, for to do otherwise would skew our interpretation of his collection and of himself. If we allow for Brownôs bias, though, there should still be no qualms with his title as ña natural historian of the Pacificò. our ñsecond lensò enables us to evaluate Brownôs context, not see past it, as we recognize that Brownô contributions and legacy deserve to be taken seriously as a recontextualized collection. ${ }^{20}$

\footnotetext{
${ }^{18}$ Richard Eves, ñCommentary: Missionary or Collector? The Case of George Brown,ò Museum Anthropology 22, no. 1 (1998): 49-50.

${ }^{19}$ Barbara Lawson, Collected Curios: Missionary Tales from the South Seas (Montreal: McGill University Libraries, 1994), 18.

${ }^{20}$ Rosman and Rubel, 67.
} 


\section{Bibliography}

Brown, George.

George Brown: D.D., pioneer-missionary and explorer : an autobiography : a narrative of forty-eight years' residence and travel in Samoa, New Britain, New Ireland, New

Guinea, and the Solomon Islands. London: Hodder and Stoughton, 1908.

Melanesians and Polynesians: Their Life Histories Described and Compared. London: Macmillan, 1910.

ñPapuans and Polynesians.ò The Journal of the Anthropological Institute of Great Britain and Ireland 16 (1887): 311-327.

Comaroff, Jean and John L. Comaroff. Of Revelation and Revolution. Chicago: University of Chicago Press, 1991-1997.

Eves, Richard. ñCommentary: Missionary or Collector? The Case of George Brown.òMuseum Anthropology 22, no. 1 (1998): 49-60.

Gardner, Helen. ñGifts, Curios and Soulsò from Gathering for God: George Brown in Oceania. (Dunedin: Otago University Press, 2006): 129-146.

Hutton, James. Missionary Life in the Southern Seas. London: Henry S. King \& Co., 1874.

Ivens, Walter G. Hints to Missionaries to Melanesia. London: Melanesian Mission Church House, Westminster, 1907.

Lawson, Barbara.

Collected Curios: Missionary Tales from the South Seas. Montreal: McGill University Libraries, 1994.

ñMissionization, Material Culture Collecting, and Nineteenth-Century Representations in the New Hebrides (Vanuatu).ò Museum Anthropology 18, no. 1 (1994): 21-38.

Rosman, Abraham and Paula G. Rubel.

ñGeorge Brown, Pioneer Missionary and Collector.ò Museum Anthropology 20, no. 1 (1996): 60-68.

ñPaula G. Rubel and Abraham Rosman Respond to Richard Eves.òMuseum Anthropology 22, no. 1 (1998): 61-63.

ñWhy They Collected: The History of Artifact Collecting in New Ireland.òMuseum Anthropology 22, no. 2 (1998): 35-49.

Sprecht, Jim. ñThe George Brown Affair Again.ò Anthropology Today 3, no. 4 (1987): 1-3. 
Stocking, George W. ñEssays on Museums and Material Cultureò from Objects and Others: Essays on Museums and Material Culture (Madison, WI: University of Wisconsin Press, 1988): 3-14.

Thomas, Nicholas.

Entangled Objects: Exchange, Material Culture, and Colonialism in the Pacific. Cambridge, MA: Harvard University Press, 1991.

ñMaterial Culture and Colonial Power: Ethnological Collecting and the Establishment of Colonial Rule in Fiji.òMan 24, no. 1 (1989): 41-56.

Whiteman, Darrell L. ñMissionary Documents and Anthropological Research.òMissionaries, Anthropologists and Cultural Change 25, no.1 (1984): 295-322. 